\title{
Analisis Program Pemberdayaan Ekonomi Rumah Tangga Miskin
}

\section{Analysis Economic Empowermence of Poor House Hold}

\author{
Ahmad Alam ${ }^{1}$, Titik Sumarti ${ }^{2}$ \\ ${ }^{1}$ Departemen Sains Komunikasi dan Pengembangan Masyarakat FEMA IPB \\ ${ }^{2}$ Dosen Departemen Sains Komunikasi dan Pengembangan Masyarakat FEMA IPB
}

\begin{abstract}
Poverty is the current problem in Indonesia, especially after financial crisis in 1997-1999. One of the institution which cares to this problem and wants to reduce poverty is Dompet Peduli Umat Daarut Tauhid (DPU DT) Bogor, by its programme, named Mikrofinance Syariah Berbasis Masyarakat (Misykat). This research is purposed to analyze realization on implementing empowerment principle and Misykat Programme on increasing economic empowermence of poor household at Kampung Loji, Kelurahan Loji, Jawa Barat. This research used Quantitatif Research Method, specifically survey technic and it is supported by qualitatif data from selected respondent. Primary, a number of respondence which participate in this research are 26 respondence, and they were women. Secondary, this research also used data from DPU DT and Kelurahan Loji. The result of this research shows that Misykat Programe had been implementing empowerment principle, such as dialogue, invention, and development. The participant economic empowermence level of the programme is high.
\end{abstract}

Keywords: Poverty, Misykat, Economic Empowermence of Poor Household.

Abstrak

Kemisikinan merupakan masalah yang umum terjadi di Indonesia terutama setelah krisis pada tahun 1997-1999. Salah satu organisasi yang pedulu dengan masalah ini dan ingin mengurangi tingkat kemiskinan adalah Dompet Peduli Umat Daarut Tauhid (DPU DT) Bogor, dengan program yang bernama Mikrofinance Berbasis Masyarakat (Misykat). Penelitian ini bertujuan untuk menganalisis realisasi dalam implementasi prinsip pemberdayaan dan program Misykat dalam meningkatkan pemberdayaan ekonomi masyarakat rumah tangga miskin di Kampung Loji, Kelurahan Loji, Jawa Barat. Penelitian ini menggunakan metode kuantitatif, yakni teknik survei dan didukung dengan data kualitatif daro responden terpilih. Pertama, responden pada penelitian ini berjumlah 26 responden dan merupakan perempuan. Kedua, penelitian ini juga menggunakan data dari DPU DT dan Kelurahan Loji. Hasil dari penelitian ini menunjukkan bahwa program Misykat telah diimplementasikan dengan menerapkan prinsip pemberdayaaan seperti dialog, penemuan(invensi) dan pembangunan. Tingkat pemberdayaan ekonomi dari partisipan tinggi.

Kata kunci: Kemiskinan, Misykat, pemberdayaan ekonomi masyarakat rumah tangga miskin

\section{Pendahuluan}

Masalah kemiskinan sekarang ini merupakan salah satu isu penting di Indonesia, terutama setelah Indonesia dilanda krisis moneter yang terjadi pada periode tahun 1997-1999. Berdasarkan data dari Badan Pusat Statistik Maret 2006 jumlah penduduk miskin sebesar 39,30 juta $(17,75 \%)$, berarti jumlah penduduk miskin turun sebanyak 3,1 juta. Selama periode Maret 2006-Maret 2007, penduduk miskin di daerah pedesaan berkurang 1,20 juta, sementara di daerah perkotaan turun sebanyak 0,93 juta orang. Persentase penduduk miskin antara daerah perkotaan dan pedesaan tidak mengalami banyak perubahan. Pada bulan Maret 2007, sebagian besar $(63,52 \%)$ penduduk miskin berada di daerah pedesaan.

Dari data BPS tahun 2007 target penurunan jumlah penduduk Indonesia di bawah garis kemiskinan nasional pada tahun 2015 adalah sebesar 7,2\%. Meskipun terjadi 
penurunan, jumlah penduduk yang tergolong miskin masih banyak. Kewajiban moral bagi semua pihak untuk melakukan sesuatu agar dapat membantu menanggulangi penduduk miskin dari ketertinggalannya. Hal ini akan tercapai jika ada upaya yang sungguhsungguh dari stakeholder yang ada yaitu pemerintah, swasta, masyarakat dan LSM untuk bekerja sama menanggulangi kemiskinan. Salah satu upaya yang bisa dilakukan adalah dengan melaksanakan program-program penanggulangan kemiskinan.

Upaya yang telah dilakukan oleh pemerintah untuk mengatasi kemiskinan antara lain melalui program beras untuk rakyat miskin (Raskin), Jaring Pengaman Sosial (JPS) untuk orang miskin, Asuransi Kesehatan untuk Orang Miskin (Askeskin), Bantuan Langsung Tunai (BLT), Impres Desa Tertinggal (IDT) dan sebagainya. Program di atas masih belum bisa menanggulangi kemiskinan terbukti jumlah penduduk miskin pada tahun 2007 masih besar yaitu 37,17 juta jiwa. Hal ini terjadi karena pelaksanaan program tersebut sampai saat ini masih bersifat top down. Program bantuan yang bersifat top down, sulit menyelesaikan persoalan kemiskinan, tetapi justru melahirkan persoalan baru seperti: konflik horizontal, ketergantungan, korupsi, disintegrasi warga, hingga melahirkan mental ,peminta-minta ${ }^{\text {ee }}$. Program-program bantuan yang berorientasi pada kedermawanan pemerintah justru dapat memperburuk moral dan perilaku masyarakat miskin (Suharto, 2005).

Berdasarkan hal di atas, upaya pengentasan kemiskinan harus mencapai kepada langkah-langkah yang nyata, dalam pemberdayaan orang miskin. Dengan demikian program penanggulangan kemiskinan difokuskan untuk membebaskan ketergantungan yang bersifat permanen baik terhadap pemerintah, swasta maupun LSM. Program bantuan tersebut dikemas dalam sebuah program penanggulangan kemiskinan dengan menggunakan konsep pemberdayaan ekonomi rumah tangga miskin yang tidak menjadikannya sebagai objek tetapi sebagai subjek dengan berlandaskan kepada konsep kemiskinan yang sudah disepakati oleh semua pihak.

Pada saat ini, telah berjalan program penanggulangan kemiskinan dari Lembaga Amil Zakat Nasional Dompet Peduli Ummat Daarut Tauhiid (DPU DT) berupa program ekonomi produktif yaitu Microfinance Syariah Berbasis Masyarakat (Misykat). Program Misykat merupakan lembaga keuangan mikro untuk orang-orang miskin yang dananya berasal dari zakat, infak, dan sedekah (ZIS) yang dikhususkan untuk pemberian modal usaha kepada kaum miskin. Ketua Badan Amil Zakat Nasional (Baznas) yaitu KH Didin Hafidhuddin, dalam milad Baznas beberapa waktu lalu melaporkan bahwa zakat yang terkumpul secara nasional pada tahun 2008 mencapai angka Rp 930 miliar. Ini berarti terjadi kenaikan sekitar Rp 160 miliar dari tahun 2007 yang mencapai Rp 770 miliar (Beik dan Sukmana, 2009). Pada tahun 2003 program Misykat DPU DT terpilih sebagai program penanggulangan kemiskinan terbaik kedua di Indonesia, serta termasuk kedalam 10 program penanggulangan kemiskinan terbaik versi Bank Dunia.

Program Misykat memiliki potensi sekaligus peranan yang cukup strategis dalam upaya pemberdayaan ekonomi rumah tangga miskin untuk menanggulangi kemiskinan melalui pembinaan dan bantuan modal usaha. Berdasarkan hal tersebut di atas, menarik untuk dikaji bagaimana pelaksanaan program Misykat dalam penanggulangan rumah tangga miskin dan sejauhmana program Misykat sudah mampu memberdayakan ekonomi rumah tangga miskin yang berada di Kampung Loji, Kelurahan Loji, Jawa Barat. Berdasarkan latar belakang di atas dapat dirumuskan pertanyaan penelitian sebagai berikut: sejauhmana tingkat pelaksanaan program Misykat dalam menerapkan prinsip pemberdayaan? sejauhmana tingkat kemiskinan rumah tangga peserta program Misykat? serta sejauhmana tingkat keberdayaan ekonomi rumah tangga peserta program Misykat? 


\section{Metodologi Penelitian}

Penelitian ini dilakukan dengan menggunakan metode penelitian kuantitatif deskriptif dengan menggunakan teknik sensus. Penelitian ini didukung dengan data kualitatif dari para Informan terpilih. Data kualitatif dikumpulkan dengan mengunakan instrumen panduan pertanyaan. Unit analisis dari penelitian ini adalah pada tingkat rumah tangga. Lokasi penelitian terletak di Kelurahan Loji, Kecamatan Bogor Barat, Kota Bogor, Provinsi Jawa Barat. Pemilihan lokasi dilakukan secara sengaja (purposive) karena lokasi tersebut merupakan salah satu Kelurahan binaan dari Dompet Peduli Umat Darut Tauhid (DPU DT) Bogor. Proses penelitian ini berlangsung mulai bulan Maret sampai bulan Agustus 2009.

Jumlah rumah tangga yang mendapatkan bantuan Misykat adalah sebanyak 30 rumah tangga, namun karena yang aktif sebanyak 26 rumah tangga maka yang diambil menjadi responden sebanyak 26 rumah tangga. Rumah tangga yang menjadi responden terdiri dari penjual makanan jajanan anak-anak, sayuran, kripik pisang, telor asin, sablon, menjahit, dan gorengan. Informan adalah orang yang mengetahui program tersebut, seperti pendamping Miskat, tokoh masyarakat Loji.

Tabel 1. Tingkat Pelaksanaan Program Misykat Berdasarkan Penilaian Peserta Program, Kelurahan Loji, 2009.

\begin{tabular}{|c|c|c|}
\hline \multirow[t]{2}{*}{ Kategori } & \multicolumn{2}{|c|}{ Jumlah responden } \\
\hline & $\mathbf{N}$ & $\%$ \\
\hline Baik : $\geq 28$ & 22 & 84,62 \\
\hline Cukup : $22-27$ & 3 & 11,54 \\
\hline Kurang : $\leq 21$ & 1 & 3,85 \\
\hline Total & 26 & 100 \\
\hline
\end{tabular}

Tabel 1 menunjukkan bahwa sebagian besar $(84,62$ persen $)$ peserta program menyatakan bahwa pelaksanaan program Misykat dinilai sudah berjalan dengan baik. Hal ini karena Pendamping program Misykat melakukan tahapan dalam pelaksanaan program pemberdayaan yaitu: tahapan dialog, penemuan dan pengembangan. Ada pun penjelasan ketiga tahapan tersebut yaitu:
Data yang digunakan dalam penelitian ini adalah data sekunder dan primer. Data sekunder berupa program Misykat, monogradi Desa diperoleh dari studi literatur serta data sekunder yang berasal dari arsip DPU DT dan Kelurahan Loji.Penelitian ini juga menggunakan alat analisis secara statistika, yaitu Uji Spearman dengan program SPSS for windows versi 13.0.

\section{Hasil Dan Pembahasan}

\section{Identifikasi Pelaksanaan Program Misykat Dalam Menerapkan Prinsip Pemberdayaan}

Proses pelaksanaan program Misykat dinilai berdasarkan tahapan dialog, penemuan dan pengembangan. Ukuran proses pelaksanaan program yang menerapkan proses pemberdayaan adalah dengan menjumlahkan skor total pada tahaptahap pelaksanaan program Misykat yang diperoleh dari masing-masing responden. Pelaksanaan program dikategorikan baik, apabila total skor penilaian responden $\geq 28$, cukup $(22-27)$ dan kurang bila skor $\leq 21$. Berikut adalah Tabel 1 yang menunjukkan tingkat pelaksanaan program Misykat berdasarkan penilaian peserta program.

\section{Tahapan Dialog}

Proses pelaksanaan program Misykat dapat dikatakan baik jika melalui tahapan pemberdayaan yaitu tahapan dialog, penemuan dan pengembangan. Tabel 2 menunjukkan bagaimana penilaian responden terhadap pelaksanaan program Misykat pada tahapan dialog. 
Tabel 2. Penilaian Peserta Program Misykat Terhadap Pelaksanaan Program Pada Tahapan Dialog, Kelurahan Loji, 2009.

\begin{tabular}{lll}
\hline \multicolumn{1}{c}{ Tahapan Dialog } & \multicolumn{1}{c}{ Jawaban } \\
\cline { 2 - 3 } & Ya n (\%) & Tidak n (\%) \\
\hline $\begin{array}{l}\text { Pendataan rumah tangga } \\
\begin{array}{l}\text { Proses musyawarah untuk pembentukan } \\
\text { kerjasama }\end{array}\end{array}$ & $22(92,3)$ & $2(7,7)$ \\
$\begin{array}{l}\text { Artikulasi tantangan atau masalah yang } \\
\text { dihadapi }\end{array}$ & $24(92,3)$ & $4(15,4)$ \\
$\begin{array}{l}\text { Identifikasi sumber potensi usaha } \\
\text { Penentuan arah usaha }\end{array}$ & $23(88,5)$ & $2(7,7)$ \\
\hline
\end{tabular}

Tabel 2 menunjukkan bahwa sebagian besar peserta program menyatakan bahwa pelaksanaan program Misykat pada tahapan dialog dinilai sudah berjalan dengan baik. Hal ini karena pada awal pelaksanaan program Pendamping program melibatkan peserta program dalam proses pendirian program seperti: 1) sosialisasi program kepada calon angota (1-3 pertemuan), 2) proses pendataan rumah tangga yang berhak menerima program berupa penyebaran, 3) pengembalian formulir pendaftaran, 4) survei dan wawancara calon anggota, dan 5) musyawarah dari Pendamping program dengan rumah tangga mengenai sumber potensi yang mereka miliki. Peserta program pun diberikan kebebasan untuk memilih usaha apa yang akan mereka jalankan serta diberikan kebebasan dalam mengembangkan usaha yang telah mereka miliki baik modal, pemasaran produk, maupun pengembangan jenis usahanya.

Tabel 3. Penilaian Peserta Program Misykat Terhadap Pelaksanaan Program Pada Tahapan Penemuan, Kelurahan Loji, 2009.

\begin{tabular}{lcc}
\hline \multicolumn{1}{c}{ Tahapan Penemuan } & \multicolumn{1}{c}{ Jawaban } \\
\cline { 2 - 3 } $\begin{array}{l}\text { Pemahaman sistem sumber: } \\
\text { a. Asal program }\end{array}$ & $9(34,6)$ & $17(65,4)$ \\
$\begin{array}{ll}\text { b. Sumber modal } \\
\text { Analisis kapasitas sumber: }\end{array}$ & $25(96,2)$ & $1(3,8)$ \\
$\begin{array}{l}\text { a. Potensi program } \\
\text { b. Keaktifan dalam pendampingan }\end{array}$ & $24(92,3)$ & $2(7,7)$ \\
$\begin{array}{l}\text { c. Frekuensi menghadiri pendampingan } \\
\text { Menyusun solusi pemecahan masalah }\end{array}$ & $24(92,3)$ & $2(7,7)$ \\
\hline
\end{tabular}

Tabel 3 menunjukkan bahwa sebagian besar peserta program menyatakan bahwa pelaksanaan program Misykat pada tahapan penemuan dinilai sudah berjalan dengan baik. Hal ini karena rumah tangga peserta program diberikan pengetahuan mengenai sistem program Misykat seperti asal program dan sumber modal pinjaman, sehingga mereka bisa memahami program Misykat. Musyawarah untuk menganalisis 
potensi wirausaha dari hasil identifikasi sumber potensi usaha dan mengambil keputusan mengenai usaha apa yang mereka akan jalankan.

Pada tahapan penemuan ada fenomena tentang pemahaman peserta program Misykat mengenai sumber modal usaha dimana banyak diantara peserta program (65,4 persen) yang tidak mengetahui sumber modal usaha berasal dari zakat, kebanyakan mereka menjawab modal usaha berasal dari sumbangan dari donatur diluar dana zakat. Hal ini diduga karena sosialisasi program Misykat hanya dilakukan diawal program saja yaitu sebanyak 1-3 kali pertemuan pada tahun 2006 dan ketika ada pergantian anggota Misykat. Sehingga sosialisasi mengenai program Misykat sebaiknya dilakukan juga minimal setahun dua kali sehingga pengetahuan mereka akan program Misykat semakin baik.

Peserta program Misykat setiap satu pekan sekali diberikan pendampingan rutin yang diisi kegiatan seperti menabung (tabungan cadangan dan tabungan berencana), pembayaran iuran wajib (iuran anggota dan iuran kas wajib majlis), dan yang paling penting lagi pemberian materi pendidikan mengenai aqidah, wirausaha, ekonomi rumah tangga, kebersihan, dan kerjasama (solidaritas). Sehingga mereka bisa bertanggung jawab dengan program Misykat yang sedang mereka jalankan dan pada pendampingan ini dibahas juga bagaimana mengatasi permasalahan seputar usaha yang sedang mereka jalankan. Namun dalam proses pendampingan rutin ini ada juga peserta yang tidak hadir $(30,8 \%)$.

Ada pun alasan mereka jarang hadir dipertemuan pekanan ini cukup beragam seperti: 1) kesibukan bekerja karena mereka sudah tidak usaha mandiri tapi bekerja disuatu perusahaan atau menjadi pembantu rumah tangga, 2) menengok keluargaa yang sakit atau meninggal dunia. 3) merasa malu karena tidak bisa membayar cicilan pinjaman walau pun Pendamping program Misykat sudah memberikan pengertian bahwa tidak bisa membayar utang jangan sampai membuat mereka tidak hadir dalam pertemuan pendampingan rutin. Berikut penuturan salah satu rumah tangga peserta program Misykat: "saya mah tidak hadir dalam pertemuan pekanan karena malu sudah lama tidak bisa membayar cicilan pinjaman, sedangkan usaha yang saya jalankan sekarang ini tidak seberapa hasilnya hanya cukup untuk kebutuhan hidup seharihari itu pun kadang tidak cukup, ditambah suami saya sekarang sudah tidak bekerja" (Ibu Rs).

\section{Tahapan Pengembangan}

Proses pelaksanaan program Misykat dapat dikatakan baik jika melalui tahapan pemberdayaan yaitu tahapan dialog, penemuan dan pengembangan. Para peserta program Misykat memperoleh pinjaman modal dari Misykat setelah mereka mengikuti pendampingan lebih dari delapan kali dan terlebih dahulu mereka harus membuat profosal pengajuan pinjaman modal untuk usaha. Besarnya pinjaman biasanya disesuaikan dengan jumlah modal yang dibutuhkan oleh peserta program. Mereka yang mau mengajukan modal harus dalam bentukkelompok, dan tiap kelompok sebanyak 5 orang yang terdiri dari empat orang anggota dan satu orang ketua kelompok.

Model pemberian dana bergulir ini mengunakan pola 2 - $2-1$ yaitu dua anggota pertama mengajukan pinjaman modal, kemudian disusul dua orang anggota lagi yang mengajukan pinjaman modal dan terakhir adalah ketua kelompok. Pemberian dana bergulir dari pola 2 ke 2 berikutnya yakni 1 bulan. Pengembalian pinjaman modal ini dilapangan terjadi kendala yang disebabkan karena usaha yang mereka jalankan ada yang gulung tikar akibat modal yang telah dipinjamkan oleh Misykat dipake biaya sekolah anaknya, dan ada juga yang terjerat reintenir.

Peserta program Misykat juga diberikan kebebasan untuk melakukan pinjaman modal diluar program Misykat seperti ke BMT dan Bank, namun para peserta program Misykat masih sedikit (30,8 
persen) yang melakukan penambahan modal usaha dengan meminjam modal usaha kepada dua lembanga keuangan mikro tersebut. Hal ini karena mereka takut tidak bisa melunasi uang pinjamannya dan lembaga keuangan mikro tersebut biasanya mensyaratkan adanya jaminan. Pada tahapan pengembangan ini pengintegrasian kemajuan-kemajuan usaha yang telah mereka capai melalui kerjasama dalam membangun usaha berjalan baik (73,1 persen), sebagai contoh berdirinya kelompok usaha telor asin yang terdiri dari 5 orang. Kelompok ini memproduksi telor asin yang dipasarkan ke lingkungan tempat tinggal mereka. Pada tahap penemuan ini juga dilaksanakan pemberian penghargaan kepada rumah tangga peserta program jika mereka menunjukkan prestasi selama program berlangsung,

\section{Tingkat Keberdayaan Ekonomi Rumah Tangga Peserta Program Misykat}

\section{Identifikasi Tingkat Keberdayaan Ekonomi Rumah Tangga Miskin Peserta Program Misykat}

Ukuran yang menyatakan tingkat keberdayaan rumah tangga peserta program Misykat diperoleh dengan menjumlahkan skor total yang diperoleh dari masing-masing responden. Responden yang memiliki tingkat keberdayaan rumah tangga tinggi adalah responden yang total skornya lebih dari atau sama dengan 19, sedangkan responden yang memiliki tingkat keberdayaan rumah tangga rendah adalah responden yang total skornya kurang dari atau sama dengan 18. Secara umum, tingkat keberdayaan rumah tangga peserta program Misykat disajikan pada Tabel 4.

Tabel 4. Jumlah Responden Berdasarkan Tingkat Keberdayaan Rumah Tangga Peserta Program Misykat, Kelurahan Loji, 2009

\begin{tabular}{lllll}
\hline \multirow{2}{*}{ No } & Kategori & \multicolumn{2}{c}{ Jumlah Responden } \\
\cline { 3 - 5 } & & \multicolumn{2}{c}{ n } \\
\hline 1 & Tinggi $: \geq 19$ & 24 & & 92,31 \\
2 & Rendah $: \leq 18$ & 2 & & 7,69 \\
\hline
\end{tabular}

Ket $n=26$

Tabel 4 menunjukkan bahwa sebagian besar peserta program Misykat tergolong kategori tingkat keberdayaan tinggi, yaitu sebesar 92,31 persen. Hal ini didukung pula oleh pernyataan salah satu peserta bahwa sebagian besar peserta program Misykat tingkat keberdayaan hidupnya semakin baik setelah mengikuti program, seperti penuturan seorang rumah tangga peserta program

\section{Hubungan Antara Tingkat Pelaksanaan Program Misykat dengan Tingkat Keberdayaan Ekonomi Rumah Tangga Peserta Program Misykat}

Semua peserta Program Misykat memiliki tabungan di Misykat hal ini karena mereka sadar akan manfaat dari menabung tersebut. Peserta program Misykat diberikan kebebasan dalam mengembangkan usaha baik menambah modal usaha dengan meminjam kepada lembaga selain dari program Misykat maupun pengembangan diversifikasi usahanya. Sehingga pelaksanaan program Misykat yang baik ini berdampak kepada tingkat keberdayaan ekonomi rumah tangga yang baik juga. Berikut penuturan salah satu peserta program:

"Alhamdulillah pendampingan rutinan setiap pekan bermanfaat pisan kanggo Ibuibu anggota Misykat. Ibu-ibu dipasihan materi cara ngelola usaha, gimana cara usaha anu halal, sareng dipasihan materi pengetahuan agama Islam. Ibu-ibu yang tadinya jarang sholat ayeuna mah getol sholat na. Jeung Ibu-ibu ayeuna mah bertambah berani contohna jadi petugas $\mathrm{MC}$ atau Tilawah kumargi tos aya jadwal na, jadi mau tidak kudu berani da udah jadwal na". (Ibu Yyh)

Berdasarkan uji statistik dengan uji Korelasi Rank Spearman, diperoleh hasil 
nilai korelasi sebesar 0,288. Hal ini mengidentifikasikan bahwa antara tingkat keberdayaan rumah tangga dengan tingkat pelaksanaan program Misykat tidak terdapat hubungan yang signifikan $(\mathrm{P}>0,05)$. Hal ini diduga karena adanya faktor-faktor lain yang mempengaruhi mengapa sebuah rumah tangga tidak berdaya pada dasarnya dapat ditelaah dari dimensi struktural dan kultural.Dimensi struktural-kultural mengandung makna berlangsungnya hubungan-hubungan sosial dan interakasi sosial yang khas dalam komunitas yang mengakibatkan berlangsungnya suatu kebiasaan yang dapat "membius" dan membatasi inisiatif dan semangat warga komunitas untuk berkembang. Berlangsungnya sikap-sikap yang pasrah, kurang kreatif, inisiatif, dan berani dalam masyarakat atau tidak langsung dapat mengekalkan bentuk-bentuk dan sifat hubungan sosial yang khas dalam komunitas termasuk dalam sebuah keluarga (Nasdian, 2006).

Dampak dari program Misykat terhadap rumah tangga peserta program Misykat secara kualitatif berdampak kepada kehidupan yang semakin baik. Hal ini karena sebanyak 26 rumah tangga peserta program Misykat dari sebelumnya tidak punya usaha kini mereka punya usaha. Ada pun 8 dari 26 peserta Misykat kini kondisinya sudah tidak berusaha lagi karena modal mereka habis dipakai untuk biaya sekolah anak, terjerat kepada reintenir dan memilih untuk bekerja. Dampak program Misykat juga ditunjukan dengan semua peserta program Misykat memiliki tabungan.

\section{Kesimpulan}

Berdasarkan pembahasan yang telah diulas pada bab-bab sebelumnya, maka dapat diambil kesimpulan sebagai berikut: Pelaksanaan program Misykat dalam menerapkan prinsip pemberdayaan telah dinilai baik oleh peserta program Misykat. Hal ini karena pendamping program Misykat melakukan tahapan dalam pelaksanaan program pemberdayaan yaitu: tahapan dialog, penemuan dan pengembangan.

Rumah tangga peserta program Misykat sebagian besar tergolong kategori rumah tangga rentan. Hal ini menunjukkan bahwa kondisi penerima program lebih baik setelah mengikuti program Misykat. Hubungan antara tingkat kemiskinan dengan tingkat pelaksanaan program Misykat tidak memiliki hubungan yang signifkan, karena baik rumah tangga miskin maupun rentan sama-sama merasakan manfaat program Misykat, sehingga rumah tangga miskin dan rentan sama-sama memberikan penilaian baik terhadap pelaksanaan program Misykat.

Pengetahuan sebagian besar peserta program Misykat tergolong kategori sedang. Hal ini dikarenakan sosialisasi program kepada calon peserta program Misykat hanya dilakukan pada awal program sebanyak 1-3 kali yaitu pada tahun 2006 dan ketika ada pergantian anggota Misykat. Tidak terdapat hubungan yang signifikan antara tingkat pengetahuan peserta terhadap Kebijakan LAZNAS DPU DT dengan tingkat pelaksanaan program Misykat. Hal ini diduga karena baik rumah tangga dengan tingkat pengetahuan sedang maupun rendah terhadap kebijakan LAZNAS DPU DT, sama-sama memberikan penilaian baik terhadap pelaksanaan program Misykat.

Rumah tangga peserta program Misykat sebagian besar sudah berdaya, hal ini menunjukkan bahwa kondisi keberdayaan dari penerima program setelah 3 tahun semakin baik. Ada pun hubungan antara tingkat keberdayaan rumah tangga dengan tingkat pelaksanaan program Misykat tidak terdapat hubungan yang signifikan. Hal ini diduga karena adanya faktor-faktor lain yang mempengarhi keberdayaan ekonomi rumah tangga seperti adanya sikap-sikap yang pasrah, kurang kreatif, inisiatif, dan berani yang dimiliki oleh rumah tangga peserta program Misykat. 


\section{Daftar Pustaka}

Bappenas. 2005. Starategi Nasional Peangulangan Kemiskinan. Sekret Kelompok Kerja Perencanaan Makro Penangulangan Kemiskinan Bappenas-Komite Penanggulangan Kemiskinan. Jakarta

Beik IS dan SukmanaR. Mengakselerasi Pertumbuhan Zakat. Repubik Opini. Harian Republika edisi Jumat, 13 Februari 2009.

BPS. 2006. Tingkat Kemiskinan Di Indonesia Tahun 2005-2006. Berita Resmi Statistika no. 47/IX/ 1 September 2006. . Tingkat Kemiskinan Di Indonesia Tahun 2007. Berita Resmi Statistika no. 38/07/th. X/ 2 Juli 2007.

Nasdian FT. 2006. Pengembangan Masyarakat (Community Development). Departemen Komunikasi dan Pengembangan Masyarakat. Fakultas Ekologi Manusia. Bogor(ID): IPB.

Suharto Edi. 2005. Membangun Masyarakat Memberdayakan Rakyat: Kajian Strategis Pembangunan Kesejahteraan Sosial Dan Pekerjaan Sosial. Bandung(ID): PT Refika Aditama.

Syahyuti. 2006. 30 Konsep Penting dalam Pembangunan Pedesaan dan Pertanian. Jakarta(ID): Bina Rena Pariwara. 